\title{
Analysis of the Transfer of Administrative Positions to Functional Positions at the Ministry of Administrative and Bureaucratic Reform
}

\author{
Istyadi Insani*, Hardi Warsono, Kismartini, Retno Sunu Astuti \\ Public Administration, Faculty of Social and Political Sciences \\ Diponegoro University \\ Semarang, Indonesia \\ *istyadi,insani@gmail.com
}

\begin{abstract}
The transfer of positions from administrative positions to functional ones is one of the implementations of the bureaucratic simplification policy to 2 levels in government agencies in Indonesia. The problem occurs because the transfer of positions was carried out in a short time without being preceded by an in-depth study. This condition has an impact on the decline in the performance of functional officials resulting from the transfer of positions which has an impact on the decline in organizational performance. This study aims to analyse the process of transferring administrative positions to functional positions in order to formulate input for improvements in policy implementation in the field. The research method uses a qualitative descriptive approach. Research informants are determined snowball with key persons of Government Officials and related functional officials. Data collection was carried out through observation, in-depth interviews, and literature study. Data analysis techniques with data reduction, presentation, and conclusion. The validity of the data using source and data triangulation techniques. Theory uses human resources management system theory. The results showed that the transfer of administrative positions to functional positions in government agencies needs to consider organizational, resource, development, reward management and employee relations factors. Recommendations in the form of policy suggestions to improve arrangements for transferring administrative positions to functional ones.
\end{abstract}

Keywords-transfer of positions, administrative position, functional position, human resources management system

\section{INTRODUCTION}

Bureaucracy is a combination of structural and poststructural approaches [1]. One of the obstacles in bureaucratic reform is its large structure [2]. Bureaucratic reform can be achieved through increasing technical efficiency in order to obtain more productive public services, especially when the need for fiscal is urgent so that it can reduce public spending and the overall tax burden [2-5].
The policy of simplifying the bureaucracy in Indonesia is not a simple matter. Many regulations have to be changed and re-harmonized through deregulation and streamlining of the organizational structure which has led to a re-bureaucratization of organizational procedures [6]. Therefore, it is necessary to have proper documentation and auditing so that every step taken can identify the pattern in order to determine the procedures that need to be trimmed. Bureaucratic simplification experiences various obstacles, one of which is a bureaucratic disease called bureunomia by Warsito Utomo in Damanhuri and Jawandi [7]. This disease affects the degree of government policy level or when it is formulated compared to the technical operational implementation of government alone [8].

One clear example of bureaucratic simplification is institutional changes and bureaucratic work procedures caused by the use of information and communication technology (ICT) as a form of innovation and the consequences of the digital era in various parts of the world today [7,9-13]. Government organizations are constantly undergoing changes in the form of reorganization and restructuring, such as major mergers, to achieve public goals and to strengthen their position in the public decision-making process [14]. In the last few decades, we have seen a move of public restructuring from New Public Management (NPM), which has brought increased vertical and horizontal specialization, to post-NPM with a focus on vertical and horizontal integration [15].

The phenomenon of simplifying the bureaucracy has appeared in several countries. Singapore, for example, has started bureaucratic simplification since 1980 and has been named one of the best countries in terms of efficient bureaucracy and reliable quality of public services. South Korea laid the foundations for simplifying the bureaucracy through various laws and regulations, such as civil service ethics, social purification movements, civil service awareness reform, control of retired civil servants, and the recruitment of civil servants. Meanwhile, the simplification of the bureaucracy in China was carried out by reducing the number of 
government ministries, departments, and agencies from 100 to 61 institutions and 30,000 party cadres were granted early retirement. As a result, Deng created an efficient, clean, anticorruption, serving and lean bureaucracy that made China currently grow into a strong economy [16-19].

The policy of simplifying the bureaucracy in Indonesia to two levels is a follow-up to President Joko Widodo's inauguration speech in the 2019-2024 government period on October 20, 2019. This policy of bureaucratic simplification is intended to shift structural positions into functional ones. The basis for this policy making is based on the composition of the state civil apparatus in 2019 which includes $10.26 \%$ or 440,029 people out of 4,286,918 people who are administrative officials. One form of implementation of this policy is the enactment of the Ministry of Administrative and Bureaucratic Reform Regulation number 28 of 2019 concerning Equalization of Administrative Positions into Functional Positions [20]. This ministerial regulation states that the equalization of administrative positions into functional positions, hereinafter referred to as transfer of positions, is the appointment of administrative officers to functional positions through adjustment/inpassing of equivalent functional positions. Implementation of this policy until June 2020, namely the transfer of administrator positions to intermediate expert functional positions totalling $2.93 \%$, executive positions to functional positions of young experts $2.53 \%$ and executing positions to first expert positions $0.49 \%$. In October 2019, the Ministry of Administrative and Bureaucratic Reform was appointed as one of the agencies implementing the bureaucratic simplification policy in Indonesia.

In transferring positions, it is necessary to consider the principle of the right man on the right place [21], namely: First, there is good job analysis that describes the scope and nature of the tasks being carried out in the organizational unit and the conditions that must be possessed by the official who will occupy the position; Second, there is a job implementation assessment of each employee who is well maintained and continuously. With this job appraisal, it can be seen about the characteristics, skills, discipline, and work performance of employees. Besides that, in transferring positions, one must pay attention to the application of a human resource management system based on the concepts of efficiency, effectiveness and economy [22]. The aspects that need to be considered include: 1) organization, 2) people resourcing, 3) learning and development, 4) reward management, and 5) employee relations [23-26]

This study aims to analyse the process of transferring administrative positions to functional positions based on a human resource management system which includes organizational aspects, people resourcing aspects, learning and development aspects, reward management aspects, and employee relations aspects. The results of this analysis are used to formulate input for improvement in the implementation of the policy of transferring administrator positions to functional positions in the Ministry of Administrative and Bureaucratic Reform that have been carried out so far. The questions that will be answered in this research are: 1) whether aspects of the human resource system affect the process of transferring administrative positions to functional positions in the Ministry of Administrative and Bureaucratic Reform? 2) how is the effect of aspects of the human resource system on the process of transferring administrative positions to functional positions in the Ministry of Administrative and Bureaucratic Reform?

\section{METHODS}

This research used a descriptive approach, and the study was conducted qualitatively [27]. Research aims to describe systematically the facts or characteristics of a particular field factually and accurately using the case study method [28]. This research focuses on the Ministry of Administrative and Bureaucratic Reform. The focus of the research is the five elements of the human resources management system associated with the transfer of administrative positions to functional positions, which include: organization, people resourcing, learning and development, reward management and employee relations, which are then made questions as the basis for interview guidelines, observation guidelines and guidelines. literature review. This research is applied with descriptive explanations. Data obtained from sources directly related to the research topic. The validity of the data was obtained by using the triangulation technique of sources and data. Research informants were selected based on the criteria of those who understand human resource management in functional positions both within the Ministry of Administrative and Bureaucratic Reform and related agencies including professional organizations and elected functional officials. The data in this study consisted of primary data obtained through in-depth interviews and observations and secondary data from literature materials related to the focus and locus of the study. Data processing and data analysis were carried out by data reduction, data presentation and drawing conclusions / conclusions $[29,30]$.

\section{RESULTS}

The policy for transferring positions can be traced to various laws and regulations, including Law Number 5 of 2014 concerning State Civil Servants [31], Government Regulation Number 11 of 2017 concerning Management of Civil Servants [32] as amended by Government Regulation Number 17 of 2020 [33], Presidential Regulation Number 47 of 2015 concerning the Ministry of Administrative and Bureaucratic Reform [34], Presidential Decree Number 87 of 1999 concerning Functional Groups [35], Regulation of the Minister of Administrative and Bureaucratic Reform Number 13 of 2019 concerning the Proposal, Determination and Development of Functional Positions [36]. The most logical reason for this policy is of course the desire to create a more dynamic and professional bureaucracy as an effort to increase the effectiveness and efficiency to support the performance of government services to the public. The Minister of Administrative and Bureaucratic Reform is of the view that the policy of transferring positions can be interpreted as equalizing 
positions through the appointment of Administrator Officers down to functional positions through adjustment or inpassing into equal positions. The criteria used are: First, job duties and functions related to functional technical services; Second, the duties and functions of the position can be carried out by functional officers; and third, positions based on certain expertise/skills.

However, the lower level administrators can still be maintained with the following criteria: First, Have duties and functions as Head of Work Units with authority and responsibility in the use of budget or users of goods / services; Second, Has duties and functions related to the authority / authority, legalization, ratification, document approval, or regional authority; and Third, criteria and other requirements of a special nature based on the recommendation of each Ministry / Institution to the Minister of Administrative and Bureaucratic Reform as a material for consideration in determining the position required for a position as Administrative Officer.

As a milestone in implementing the policy of transferring administrator positions to functional positions, the issuance of Minister of Administrative and Bureaucratic Reform Regulation number 28 of 2019 concerning Equalization of Administrative Positions into Functional Positions on December 6, 2019 as a legal confirmation of the Circular of the Minister of Administrative and Bureaucratic Reform Number 384, 390 and 391 of 2020 concerning Strategic and Concrete Steps to Simplify the Bureaucracy addressed to the Ministers of the Advanced Indonesian Cabinet, Governors and Regents / Mayors throughout Indonesia which were issued on November 13, 2019. The Circular of the Minister of Administrative and Bureaucratic Reform states that bureaucratic simplification This is intended to create a bureaucracy that is more dynamic, agile, and professional in an effort to increase the effectiveness and efficiency to support the performance of government services to the public. This was followed by efforts to improve the competence of State Civil Service Employees. This Circular Letter contains strategic and concrete steps that must be taken including identification, mapping, alignment of needs, socialization, carrying out the transformation process, and transferring administrative positions to functional positions.

The Ministry of Administrative and Bureaucratic Reform as the ministry that organizes government affairs in the field of the state apparatus is appointed as the agency that first applies the transfer of administrative positions to functional positions. Of the existing 141 administrative positions, $97.87 \%$ were transferred, consisting of $98.07 \%$ Ahli Madya and $77.43 \%$ Ahli Muda (table 1).

TABLE I. NUMBER OF ADMINISTRATIVE POSITIONS TRANSFERRED TO FUNCTIONAL POSITIONS AS OF JUNE 2020 AT THE MINISTRY OF ADMINISTRATIVE AND BUREAUCRATIC REFORM

\begin{tabular}{|c|l|l|l|l|l|l|}
\hline \multicolumn{2}{|c|}{ Administration Position } & \multicolumn{3}{|c|}{$\begin{array}{c}\text { Positions that change to } \\
\text { Functional Positions }\end{array}$} & \multirow{2}{*}{ Information } \\
\hline Type & Number & Level & Number & $\%$ & \\
\hline Administrator & 52 & $\begin{array}{l}\text { Ahli } \\
\text { Madya }\end{array}$ & 51 & 98,07 & $\begin{array}{l}\text { Left with 1 } \\
\text { administrator } \\
\text { position and 2 }\end{array}$ \\
\hline Supervisory & 89 & Ahli & 87 & 77,43 & & \\
\hline
\end{tabular}

\begin{tabular}{|c|l|l|l|l|l|}
\hline & & Muda & & & $\begin{array}{l}\text { supervisory } \\
\text { positions }\end{array}$ \\
\hline Total number & 141 & $\begin{array}{l}\text { Total } \\
\text { number }\end{array}$ & 138 & 97,87 & \\
\hline
\end{tabular}

Ministry of Administrative and Bureaucratic Reform, 2020

Strategic Steps of Bureaucratic Simplification at the Ministry of Administrative and Bureaucratic Reform: First, Identifying Echelon III and Echelon IV work units that can be simplified and shifted their structural positions according to the job map starting October 2019; Second, Mapping the positions and structural officers of Echelon III and Echelon IV in work units affected by the transition and at the same time identifying the equivalence of these positions with functional positions that will be occupied in October 2019; Third, Mapping functional positions that can and are needed to accommodate the transition of Echelon III and Echelon IV structural officials who were affected by cuts as a result of the bureaucratic simplification policy in October 2019; Fourth, Aligning budget requirements related to income in positions affected by the November 2020 bureaucratic simplification policy; Fifth, Carry out socialization and provide understanding to all employees regarding the policy of simplifying the bureaucracy, so that each employee can adjust to a dynamic, agile and professional organizational structure in order to improve organizational performance and public services in November 2019; Sixth, Submission of simplification activity proposals to the Minister of Administrative and Bureaucratic Reform in the form of softcopy in December 2019; Seventh, Determination of the Organizational Structure and Work Procedure of the Minister of Administrative and Bureaucratic Reform which is the result of simplifying the bureaucracy in December 2020; Eighth, The process of transforming Echelon III, and Echelon IV structural positions into functional positions is carried out based on the mapping results in January 2020; Ninth, Carry out a transfer of positions in a professional manner, free from corruption, and without conflicts of interest while still applying the principle of prudence, in line with good governance, and guided by the provisions of the legislation in February 2020; dan Tenth, Carry out follow-up of personnel administration documents in the transfer of structural positions Echelon III and Echelon IV to further functional positions in the Regulation of the Minister for Administrative and Bureaucratic Reform through the appointment of inpassing/adjustments to functional positions specifically in February 2020.

\section{DISCUSSION}

The implementation of the transfer of administrative positions to functional positions in the Ministry of Administrative and Bureaucratic Reform, if it is linked to the concept of human resource management of state civil servants (ASN management), the following can be identified: First, there is a change in functional position with the promulgation of a Government Regulation Number 17 of 2020 concerning Amendments to Government Regulation Number 11 of 2017 concerning Management of Civil Servants. This condition affects the preparation and determination of needs and their procurement; Second, ranks and positions for functional 
positions have not yet been determined considering that the applicable rank provisions are still pending the stipulation of the Government Regulation on Salary and Allowances; Third, career patterns and career development for functional positions still require implementing regulations for the Ministry of Administrative and Bureaucratic Reform Regulations concerning functional positions, especially on placement policies, certification and competency tests at the time of transfer of positions; Fourth, promotions and transfers for functional positions still require clarity considering that functional positions are related to other functional professions that are in the same office and have a cross section of duties and functions; Fifth, the performance appraisal for functional positions still uses the employee performance target assessment (SKP) pattern with the old provisions based on Government Implementation Regulation Number 46 of 2011 concerning Civil Servant Performance Assessment; Sixth, the remuneration and allowances and awards received by functional positions are lower than the equivalent structural positions before the transfer of positions; and Seven, the provisions regarding discipline, dismissal, pension security and old age security as well as protection for functional positions are still the same as those prior to the implementation of the position transfer policy.

The research was conducted by using qualitative methods and using primary data obtained through in-depth interviews. Limitations in this study include the subjectivity of the researcher. This research is highly dependent on the researcher's interpretation of the implied meaning of the interview so that the tendency to bias remains. To reduce bias, a triangulation process is carried out, namely triangulation of sources and methods. Source triangulation was done by cross checking the data with the facts from different informants and from other research results. While the method triangulation is done by using several methods in data collection, namely indepth interviews, and observation methods.

\section{CONCLUSION}

The results showed that aspects of the human resource system affected the process of transferring administrative positions to functional positions in the Ministry of Administrative and Bureaucratic Reform. The influence of aspects of the human resource system on the process of transferring an administrative position to a functional position in the Ministry of Administrative and Bureaucratic Reform includes clarity of position in the organization, availability of resources, competency development, management of reward management and clarity of relations between employees. Aspects of the human resource system affect the process of transferring positions both before, during and after the transfer of positions. Recommendations that can be given are that the transfer of administrative positions to functional ones needs to be carried out through in-depth studies, preparing preconditions for employees to prepare themselves, planning employee careers and preparing an equal compensation system and drafting a work relationship in accordance with organizational changes.

\section{REFERENCES}

[1] S. Dischner, "Organizational structure, organizational form, and counterproductive work behavior: a competitive test of the bureaucratic y post-bureaucratic views," Scandinavian Journal of Management, vol. 31, no. 4, pp. 501-514, 2015

[2] E. Prasojo and D. Holidin, "Leadership and management development The Indonesian experience," In Knowledge Creation in Public Administrations (pp. 237-256). Palgrave Macmillan, Cham, 2018.

[3] Z. Asatryan, F. Heinemann and H. Pitlik, "Reforming the public administration: The role of crisis and the power of bureaucracy," European Journal of Political Economy, vol. 48, pp. 128-143, 2017.

[4] E. Prasojo, T. Kurniawan and D. Holidin, State Reform in Indonesia. Depok: Admistrative Science Departement, Univesity of Indonesia, 2007.

[5] K. Angelopoulos, A. Philippopoulos and E. Tsionas, "Does public sector efficiency matter? Revisiting the relation between fiscal size and economic growth in a world sample," Public choice, vol. 137, no. (1), pp. 245-278, 2008.

[6] K. Størkersen, T. Thorvaldsen, T. Kongsvik and S. Dekker, "How deregulation can become overregulation: an empirical study into the growth of internal bureaucracy when governments take a step back," Safety science, vol. 128, pp. 104772, 2020.

[7] D. Damanhuri and R. Jawandi, "Reaktualisasi reformasi birokrasi menuju good governance," Prosiding Seminar Nasional Pendidikan FKIP, vol. 1, no. 2, 2017.

[8] H. Pasolong, Teori Administrasi Publik. Bandung: Alfabeta, 2011.

[9] R. Giri, "Use of ICT in Administrative Reform: Prospects and Challenges," International Journal of Science Technology Engineering \& Management (IJSTEM), vol. 1, no. 1, 2020.

[10] E.A. Purwanto, "Smart city as an upshot of bureaucratic reform in Indonesia," International Journal of Electronic Government Research (IJEGR), vol. 14, no. (3), pp. 32-43, 2018.

[11] O.M. Okunola, J. Rowley and F. Johnson, "The multi-dimensional digital divide: Perspectives from an e-government portal in Nigeria," Government Information Quarterly, vol. 34, no. (2), pp. 329-339, 2017.

[12] M. Nishijima, T.M. Ivanauskas and F.M. Sarti, "Evolution and determinants of digital divide in Brazil (2005-2013)," Telecommunications Policy, vol. 41, no. (1), pp. 12-24, 2017.

[13] L. Puspitasari and K. Ishii, "Digital divides and mobile Internet in Indonesia: Impact of smartphones," Telematics and Informatics, vol. 33, no. (2), pp. 472-483, 2016

[14] C. Pollitt and G. Bouckeart, Public Management Reform: A Comparative Analysis - New Public Management, Governance, and the Neo-Weberian State. 3rd ed. Oxford: Oxford University Press, 2011.

[15] T. Christensen and P. Lægreid, "The Whole-of-Government Approach to Public Sector Reform," Public Administration Review, vol. 67, no. (6), pp. 1059-1066, 2007.

[16] E. Prasojo and T. Kurniawan, "Reformasi Birokrasi dan Good Governance: Kasus Best Practices dari Sejumlah Daerah di Indonesia," In The 5 th International Symposium of Jurnal Antropologi Indonesia, pp. 1-15, 2008.

[17] G. Liu, Zhenfu jigou gaige Ji yunzou quanshu, (Handbook of Chinese government reforms and practices). Zhongyang dangxiao chubanse, 1998.

[18] G. Mao, "Public Administration, of the Government, by the Government, for the Government: on the Xing Zheng Guan Li Xue of China (in Japanese)," The MeijiGakuin La,v RevielV, vol. 68, 1999. 
[19] G. Mao, "On governmental reform in China: Two suggestions from Japanese experiences," Chinese Public Administration Review, vol. 2, no. 1/2, pp. 20-36, 2016

[20] Ministry of Administrative and Bureaucratic Reform Regulation number 28 of 2019 concerning Equalization of Administrative Positions into Functional Positions.

[21] A.Y.S. Rahayu and K.P. Rahmayanti, "The Tendency of Transition from Structural to Functional Positions in National Civil Service Agency and the Ministry of Environment and Forestry," Policy \& Governance Review, vol. 2, no. (3), pp. 191-203, 2019.

[22] R.A. Chapman, Strategies for reducing government activities. Strategies for Administrative Reform. Lexington Massachusetts: Lexington Books, 1982.

[23] M. Armstrong and S. Taylor, Armstrong's handbook of human resource management practice. Kogan Page Publishers, 2020.

[24] H. Ho and B. Kuvaas, "Human resource management systems, employee well-being, and firm performance from the mutual gains and critical perspectives: The well-being paradox," Human Resource Management, vol. 59, no. (3), pp. 235-253, 2020.

[25] N. Febriyanti and A.F.A. Ihsani, "Development Strategy of Human Resource Management For Millennial Generation,” AFEBI Management and Business Review, vol. 4, no. (02), pp. 105-116, 2020.
[26] F. Hecklau, M. Galeitzke, S. Flachs and H. Kohl, "Holistic approach for human resource management in Industry 4.0," Procedia Cirp, vol. 54, no. (1), pp. 1-6, 2016.

[27] L.J. Moleong, Metodologi Penelitian Kualitatif. Cetakan ke-16. Bandung. Remaja Rosdakarya, 2011.

[28] R.K. Yin and D. Robert, Studi Kasus: Desain dan Metode Kualitatif. Jakarta: Rajawali Pers, 2011.

[29] A.M. Huberman and M.B. Miles, Manajemen data dan metode analisis. Handbook of qualitative research, 2009.

[30] Sugiyono, Metode Penelitian Kualitatif. Bandung: Alfabeta, 2017.

[31] Law Number 5 of 2014 concerning State Civil Apparatus.

[32] Government Regulation Number 11 of 2017 concerning Management of Civil Servants.

[33] Government Regulation Number 17 of 2020 concerning Amendments to Government Regulation Number 11 of 2017 concerning Management of Civil Servants.

[34] Presidential Regulation Number 47 of 2015 concerning Ministry of State Apparatus Empowerment and Bureaucratic Reform.

[35] Presidential Decree Number 87 of 1999 concerning Functional Groups.

[36] Ministry of Administrative and Bureaucratic Reform Regulation Number 13 of 2019 concerning Proposal, Determination and Development of Functional Positions. 